\title{
Influence of Rice Straw Incorporation on the Microbial Biomass and Activity in Coastal Saline Soils of Bangladesh
}

\author{
Nasrin Chowdhury \\ Department of Soil Science, University of Chittagong, Chittagong, Bangladesh \\ Email: nasrin@cu.ac.bd
}

How to cite this paper: Chowdhury, N. (2016) Influence of Rice Straw Incorporation on the Microbial Biomass and Activity in Coastal Saline Soils of Bangladesh. Open Journal of Soil Science, 6, 159-173. http://dx.doi.org/10.4236/ojss.2016.610016

Received: September 12, 2016

Accepted: October 9, 2016

Published: October 12, 2016

Copyright $\odot 2016$ by author and Scientific Research Publishing Inc. This work is licensed under the Creative Commons Attribution International License (CC BY 4.0).

http://creativecommons.org/licenses/by/4.0/ (c) (i) Open Access

\begin{abstract}
Coastal soils of Bangladesh are affected by salinity. This study investigated salinity as a stress factor on coastal soils in Bangladesh. It was also observed if incorporation of rice straw could remediate negative impacts of soil salinity (if any) on microbial activity. The microbial biomass carbon ranged from 137.85 to $614.88 \mu \mathrm{g} / \mathrm{g}$ among the soils $(\mathrm{n}=11)$. Microbial biomass carbon content and number of both cultivable bacteria and fungi decreased in the soils with higher $E C_{\mathrm{e}}$ (electrical conductivity). Respiration was measured over 30 days with each soil pre incubated at $50 \%$ of water holding capacity. Basal respiration rate as well as soil organic carbon content ( $r=$ $0.88, p<0.05)$ increased with increasing $E C_{e}$ of soils. The cumulative basal soil respiration was higher in the soils with higher salinity $(4.81-37.73 \mathrm{mS} / \mathrm{cm})(12.91-$ $16.89 \mathrm{mg} \mathrm{CO} / \mathrm{g}$ dry soil $)$ than in the nonsaline soils $(0.98-2.33 \mathrm{mS} / \mathrm{cm})(5.79-6.51$ $\mathrm{mg} \mathrm{CO}_{2} / \mathrm{g}$ dry soil). Application of rice straw at $0.50 \%, 1.00 \%, 1.50 \%$ and $2.00 \%$ reduced the negative impact of soil salinity especially at higher $E C_{e} s(6.63-37.73$ $\mathrm{mS} / \mathrm{cm}$ ). Application of $1.00 \%$ rice straw appeared to be acceptable for successful amelioration of saline soils of the study area.
\end{abstract}

\section{Keywords}

Soil Salinity, Osmotic Potential, Respiration, Substrate, Amelioration

\section{Introduction}

Salt in soil is one of the most important environmental problems of Bangladesh. Reduction of freshwater flow from upstream causes salinity intrusion and salinization of ground water in Bangladesh [1]. The coastal area covers about $20 \%$ of total land and over $30 \%$ of the net cultivable area of Bangladesh [2]. Salinity affected around 53\% of 
coastal soils of the country [1], however, soil salinity fluctuates with seasons in this area. Rice (Oryza sativa L.) is the main crop in the coastal zone cultivated mainly rain fed during the monsoon when soil salinity is lowered.

Soil microorganisms are important labile fraction of soil organic matter. Any negative impact on soil microbial properties is of great concern as this can affect nutrient cycles as well as the soil fertility [3]. In the dry season, low water content and increased salinity are common in coastal soils of Bangladesh [1] and these can be important stresses for soil microbial communities in this area. Both matric potential (a measure of how strongly the water is held onto soil surfaces) and osmotic potential (a function of the concentration of soluble salts in the soil solution) need to be considered to understand better what happens to the microbial biomass and its activity in saline soils [4]. When the water content of the saline soil decreases; the salt concentration in the soil solution increases. Microorganisms are then subjected to different osmotic potentials as the salt concentration changes. Salinity can stress or even kill soil microorganisms. Soil microorganisms need more energy to retain water and produce osmolytes to tolerate stress for excess salt in soil [5]. Supply of organic residues can help microorganisms to compensate the excess salt in solution. So, saline soils could be ameliorated for enhanced crop growth through application of organic residues. Coastal soils of Bangladesh are poor in organic matter content [6]. Crop residues are not recycled in this soil but used as fuel and fodder in regular practice. Very little is known about the amelioration of saline soils with crop residues, particularly in the area taken for the present study. Therefore, an incubation experiment was conducted after application of different levels of rice straw to study the improvements of microbial activity communities to gradient of salinity.

\section{Materials and Methods}

\subsection{Study Area and Soil Sampling}

The study site was situated at the coastal saline region of Baharchara and Kalipur union ( 4511 hectare, $21^{\circ} 51^{\prime} \mathrm{N}$ and $22^{\circ} 11^{\prime} \mathrm{N}, 91^{\circ} 51^{\prime} \mathrm{E}$ and $92^{\circ} 03^{\prime} \mathrm{E}$ ) of Banshkhali thana in the Chittagong district, Bangladesh with the Bay of Bengal on the west (Figure 1). It was classified as Chittagong Coastal Plain (Agroecological zone 23) grey piedmont soils (saline part) according to the General soil type (GST) which is correlated as Gleysols soil (FAO-UNESCO soil unit) [7].

Sampling sites were selected from different agricultural lands which were used for rice cultivation. This region is typically monsoonal. The average maximum temperature is $32.3^{\circ} \mathrm{C}$ during May, and the minimum, $13.9^{\circ} \mathrm{C}$ in January. The annual average rainfall is $2877 \mathrm{~mm}$. The average maximum relative humidity reaches $97 \%$ during September, and the minimum, 38\% in March. Cultivation is not possible in most of the lands during the dry season (January-May) because of high salt content in soil solution [8].

Soil samples with variable salinity were collected from the soil surface to the root zone $(0-20 \mathrm{~cm})$ in the month of April, 2014, the dry season, after harvesting the rice from the filed. Composite soil sampling technique was followed taking three 


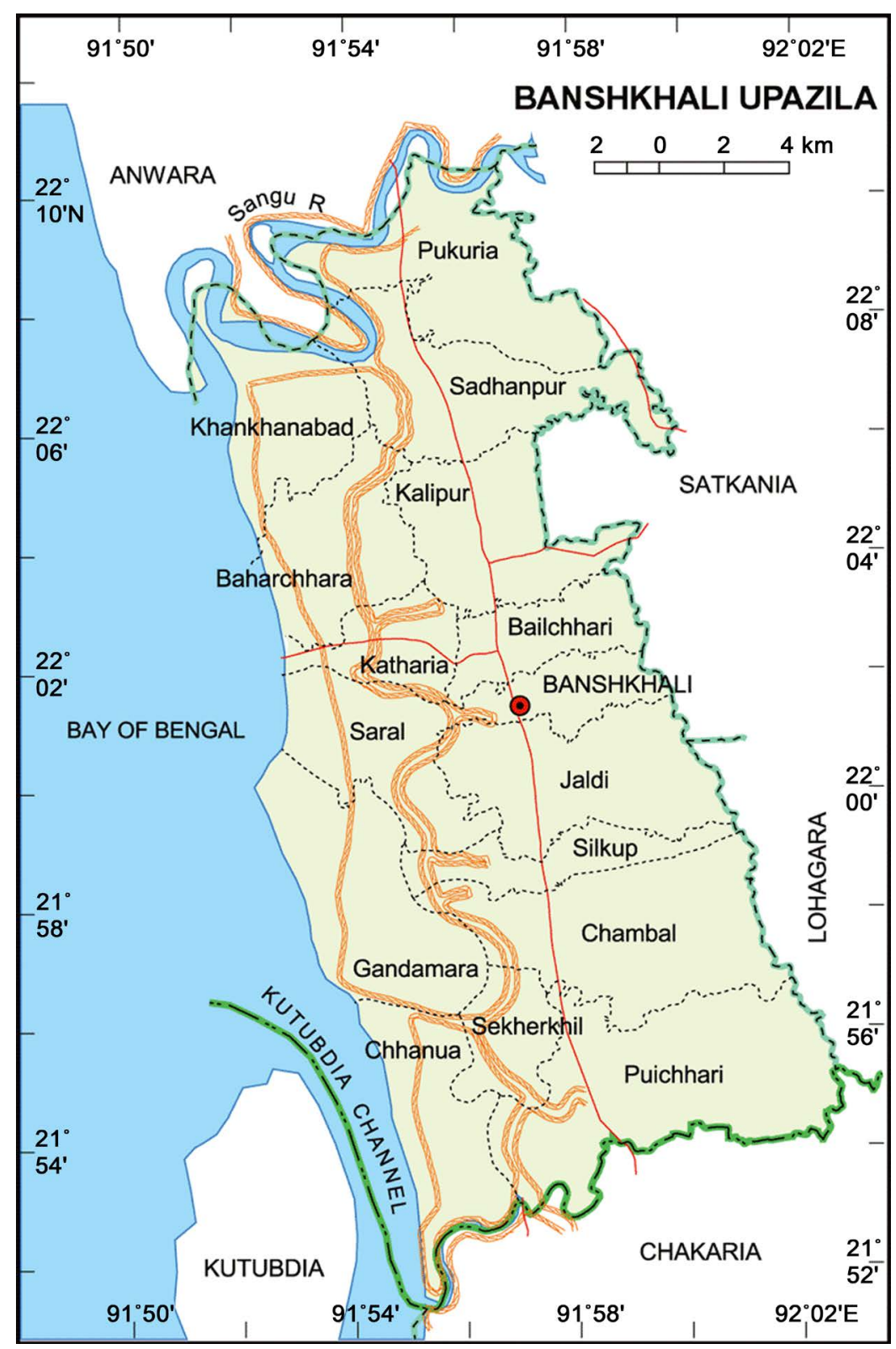

Source of base map: http://wikimapia.org/9385803/BanshkhaliUpazila.

Figure 1. Sampling location of the Banshkhali upazila, Chittagong, Bangladesh.

representative samples from each site. After removing the visible organic matters, soil samples were air dried and sieved through a $2 \mathrm{~mm}$ mesh sieve. Physical and chemical properties were analyzed on air dried sub samples. Microbiological parameters and the subsequent incubation experiment were performed after each soil was pre incubated at $50 \%$ of water holding capacity for ten days. Thus only the osmotic stresses of soil salinity on soil microorganisms were considered minimizing the matric stress of low water contents of the saline soils. The results presented in the paper are arithmetic means and expressed on an oven dry basis $\left(24\right.$ hour at $\left.105^{\circ} \mathrm{C}\right)$. Eleven soil samples were selected out of twenty one according to the electrical conductivity (EC) of the soils $\left(\mathrm{EC}_{1: 5} 0.10\right.$ 
$\mathrm{mS} / \mathrm{cm}-4.10 \mathrm{mS} / \mathrm{cm}$ ) to cover the range that may impact soil microbial activities. Salinity increased from plain lands towards sea side.

\subsection{Measurement of Soil Chemical and Physical Properties}

General soil characteristics were determined following the standard procedures. $E C_{1: 5}$ of the soils was determined at a ratio of soil: water $=1: 5$ according to the method in [9]. The $E C_{1: 5}$ were converted to the electrical conductivity of saturated paste $\left(E C_{e}\right)$ of the soils using Equation (1) [10],

$$
E C_{e}=(14.00-0.13 \times \text { clay } \%) \times E C_{1: 5} .
$$

The osmotic potential was estimated according to Equation (2) [9],

$$
O_{s}=-0.036 E C_{\text {meas }}\left(\theta_{\text {ref }} / \theta_{\text {act }}\right)
$$

where, $O_{s}=$ the soil osmotic potential $(\mathrm{MPa})$ at the actual moisture content $\left(\theta_{a c t}, \mathrm{~g} / \mathrm{g}\right)$ of the soil and $E C_{\text {meas }}=$ the measured electrical conductivity $(\mathrm{mS} / \mathrm{m})$ of the extract at the reference water content $\left(\theta_{\text {ref }}, \mathrm{g} / \mathrm{g}\right.$ ) of the 1:5 soil/water mixture.

Equation (2) is based on van't Hoff's law, and [11] showed that there is a linear relationship between EC, total cations in the soil solution and osmotic potential. The relationship between salt concentration in the soil, water content and osmotic potential is shown in [9]. The $\mathrm{pH}$ of the soil samples were measured by a $\mathrm{pH}$ meter at dry soil and distilled water ratio of 1:5 as described in [12]. Particle size distributions of the soils were determined by the hydrometer method [13]. Textural classes were determined using "soil automatic texture calculator" by Natural Resources Conservation Service Soils of the United States Department of Agriculture. Organic carbon content of the soil samples were determined volumetrically by the wet oxidation method as in [14]. Water holding capacity of soil was determined volumetrically [12].

\subsection{Measurement of Soil Microbiological Properties}

\subsubsection{Enumeration of Soil Microbial Population}

Number of culturable bacterial and fungal cell numbers in soils was counted using the dilution plate method as described in [15]. Nutrient agar medium was used for bacteria and potato dextrose agar medium for fungi. Three plates were used for each soil. The plates were incubated at $28^{\circ} \mathrm{C}$ for 72 to 120 hours and counting made for colonies.

\subsubsection{Microbial Biomass Carbon}

Biomass carbon was measured by the method described as in [16]. The microbial cells in soil were killed by fumigation with ethanol free chloroform. Immediately after preincubation, duplicate, $5 \mathrm{~g}$ subsamples for each were taken in falcon tubes. One set of samples was fumigated with ethanol free chloroform for 24 hours at $25^{\circ} \mathrm{C}$ in a sealed desiccator. Nonfumigated set of samples in falcon tubes were capped and stored at $8^{\circ} \mathrm{C}$. After fumigant removal, both fumigated and nonfumigated soils were extracted with freshly prepared $0.50 \mathrm{M}$ potassium sulphate at 1:4 ratios and filtered. Dissolved organic carbon in the extracts was determined after dichromate digestion by titrating with 0.03 $\mathrm{M}$ acidified ferrous ammonium sulphate. The amount of microbial biomass carbon was 
calculated according to Equation (3),

$$
\text { Microbial biomass carbon }=E_{c} / k_{e c} \text {, }
$$

where, $E_{c}=$ (organic carbon extracted from fumigated soils) - (organic carbon extracted from non-fumigated soils) and $k_{e c}=0.45[17]$.

\subsubsection{Metabolic Quotient}

Stress in the microbial population can be determined by the metabolic quotient $\left(\mathrm{qCO}_{2}\right)$. Organic carbons in soil generally undergo microbial synthesis and are converted to humus. But, in the case of increased stress, more $\mathrm{CO}_{2}$-carbon per unit microbial biomass per unit time is produced to counter stress [18]. The metabolic quotient was calculated from basal respiration at the end of the 30 days incubation period according to (4) [19],

$$
\mathrm{qCO}_{2}=\left(\mathrm{mg} \mathrm{CO} \mathrm{CO}_{2} \mathrm{C} / \text { day } / \mathrm{g} \text { soil }\right) /(\mathrm{mg} \mathrm{SMB}-\mathrm{C} / \mathrm{g} \text { soil })=r / \mathrm{SMB}-\mathrm{C}
$$

where, $r$ is the respiration rate $\left(\mathrm{mg} \mathrm{CO}_{2}-\mathrm{C} / \mathrm{day} / \mathrm{g}\right.$ soil) and SMB-C is the soil microbial biomass carbon (mg C/g soil).

\subsubsection{Microbial Activity}

Microbial activity was determined by soil respiration, trapping the carbon dioxide $\left(\mathrm{CO}_{2}\right)$ in sodium hydroxide $(\mathrm{NaOH})$ which was evolved from the soil during incubation in a closed system [20]. The trapped $\mathrm{CO}_{2}$ was determined by measuring electrical conductivity [21]. For this purpose, $50 \mathrm{~g}$ (oven dry basis) moist pre incubated soil was placed in 1 liter capacity incubation Jars. Ten $\mathrm{ml}$ of $1.00 \mathrm{M} \mathrm{NaOH}$ solution in $50 \mathrm{ml}$ falcon tubes were placed in each jar as the $\mathrm{CO}_{2}$ trap. A falcon tube with water was added into the jar to maintain the soil moisture. Jars were made air tight immediately. Two jars with $1.00 \mathrm{M} \mathrm{NaOH}$ but without soil were used as controls. All jars were incubated at $25^{\circ} \mathrm{C} . \mathrm{CO}_{2}$ absorbed in traps were analyzed at $1,7,14,30$ days of $\mathrm{NaOH}$ placement. Each time fresh $\mathrm{NaOH}$ solution $(10 \mathrm{ml})$ was replaced to trap $\mathrm{CO}_{2}$ for the next days. In this method, $\mathrm{CO}_{2}$ evolved from each sample was calculated as the difference between the initial and the $\mathrm{CO}_{2}$ concentration after each measurement period. Basal respiration rate was calculated based on cumulative $\mathrm{CO}_{2}$ evolution over the 30 day period.

\subsubsection{Potential Mineralizable Carbon}

The potential mineralizable carbon was estimated after 30 day incubation period according to first order kinetic Equation (5),

$$
C_{m}=C_{0}\left(1-1 / e^{k t}\right)
$$

where, $C_{m}$ is the actual mineralized carbon or $\mathrm{CO}_{2}$ evolved at time $t, C_{0}$ is the potential mineralizable $C$ pool and $k$ is the rate constant.

\subsubsection{Microbial Biomass and Activity Related to Rice Straw Incorporation}

An incubation experiment was conducted with three replicates of moist soil (pre incubated at $50 \%$ of water holding capacity for 10 days) of each $E C_{e}^{\text {'s }}$ (S1-S11). The soils were incubated with rice straw (40\% carbon, $1 \%$ nitrogen). Rice straw (ground and 
sieved at $0.25-2.00 \mathrm{~mm}$ ) was thoroughly mixed into the soil samples at five different levels on dry weight basis $(0.00 \%, 0.50 \%, 1.00 \%, 1.50 \%$, and $2.00 \%)$. Microbial biomass carbon and soil respiration were assessed as stated above.

\section{Statistical Analyses}

Statistical analyses of data were conducted using Microsoft Excel and SPSS software. Pearson correlations between parameters were performed $(p<0.05)$ in order to see relationship between the different parameters measured. ANOVA followed by Duncan's post hoc test $(p<0.05)$ were performed to determine the statistical significance of the difference between amended soils and controls.

\section{Results and Discussion}

\subsection{Characterization of the Coastal Soils}

Physical and Chemical Properties of Soils

The $E C_{e}$ of the soils varied significantly, ranging from $0.98 \mathrm{mS} / \mathrm{cm}$ to $37.73 \mathrm{mS} / \mathrm{cm}$ (Table 1). Soils are generally classified as saline when they have an $E C_{e}$ of $4 \mathrm{mS} / \mathrm{cm}$ or more [9]. Soil samples $\mathrm{S} 1\left(E C_{e} 0.98 \mathrm{mS} / \mathrm{cm}\right)$ and $\mathrm{S} 2\left(E C_{e} 2.33 \mathrm{mS} / \mathrm{cm}\right)$ were nonsaline, whereas the remaining nine other soils were saline $\left(E C_{e} 4.81-37.73 \mathrm{mS} / \mathrm{cm}\right) . E C_{e} 4.81$ $\mathrm{mS} / \mathrm{cm} \mathrm{(S3),} 4.90 \mathrm{mS} / \mathrm{cm}$ (S4), $6.16 \mathrm{mS} / \mathrm{cm}$ (S5), $6.63 \mathrm{mS} / \mathrm{cm}$ (S6) and $8.13 \mathrm{mS} / \mathrm{cm}$ (S7) were moderately saline, $E C_{e} 16.03 \mathrm{mS} / \mathrm{cm}$ (S8) was highly saline and $E C_{e} 20.09 \mathrm{mS} / \mathrm{cm}$ (S9), $25.89 \mathrm{mS} / \mathrm{cm} \mathrm{(S10)} \mathrm{and} 37.73 \mathrm{mS} / \mathrm{cm}$ (S11) were extremely saline soils. Salt concentration in coastal saline soils changes as the saline groundwater in the coastal region goes to rapid evaporation through capillary action during the summer months [22].

Table 1. Major physical and chemical characteristics of the soils used for this study. [EC (Electrical conductivity at 1:5 soil water ratio), $E C_{e}$ (Electrical conductivity at saturated paste condition), Os (Osmotic potential), MC (moisture content), OC (Organic carbon)].

\begin{tabular}{cccccccccc}
\hline $\begin{array}{c}\text { Soil } \\
\text { Sample }\end{array}$ & $\begin{array}{c}\text { USDA soil } \\
\text { subgroup }\end{array}$ & $\begin{array}{c}\mathrm{EC} \\
(\mathrm{mS} / \mathrm{cm})\end{array}$ & $\begin{array}{c}E C_{e} \\
(\mathrm{mS} / \mathrm{cm})\end{array}$ & $\begin{array}{c}\mathrm{Os} \\
(\mathrm{Mpa})\end{array}$ & $\mathrm{pH}$ & $\begin{array}{c}\mathrm{MC} \\
(\%)\end{array}$ & $\begin{array}{c}\text { OC } \\
(\%)\end{array}$ & $\begin{array}{c}\text { Clay } \\
(\%)\end{array}$ & Texture \\
\hline S1 & Dystric Eutrochrepts & 0.13 & 0.98 & -0.06 & 5.03 & 21.43 & 1.05 & 49.96 & Clay \\
S2 & Plinthic Haplustults & 0.30 & 2.33 & -0.14 & 6.64 & 17.99 & 0.91 & 47.86 & Clay \\
S3 & Typic Hapludults & 0.59 & 4.81 & -0.27 & 5.26 & 17.20 & 1.16 & 44.38 & Clay \\
S4 & Plinthic Haplustults & 0.61 & 4.9 & -0.30 & 4.85 & 3.62 & 1.17 & 45.91 & Clay \\
S5 & Dystric Eutrochrepts & 0.76 & 6.16 & -0.35 & 5.19 & 2.41 & 1.19 & 45.34 & Clay \\
S6 & Typic Haplaquepts & 0.80 & 6.63 & -0.40 & 5.29 & 4.93 & 1.29 & 43.92 & Clay \\
S7 & Typic Haplaquepts & 0.94 & 8.13 & -0.43 & 4.70 & 3.88 & 1.52 & 40.83 & Clay \\
S8 & Typic Haplaquepts & 1.96 & 16.03 & -0.96 & 5.36 & 6.43 & 1.49 & 44.62 & Clay \\
S9 & Typic Haplaquepts & 2.40 & 20.09 & -1.13 & 4.51 & 3.29 & 1.59 & 43.17 & Clay \\
S10 & Typic Haplaquepts & 3.06 & 25.89 & -1.38 & 4.50 & 7.87 & 1.89 & 42.60 & Clay \\
S11 & Typic Haplaquepts & 4.09 & 37.73 & -1.86 & 4.43 & 6.75 & 1.69 & 43.60 & Clay \\
Pearson & correlation with ECe & & & & -0.58 & $-0.37^{*}$ & 0.88 & -0.52 & \\
\hline
\end{tabular}

*Correlation is significant at the 0.05 level. 
The salt deposited on the surface of the coastal soil increases the salinity of the soil. According to the report [8], the cationic preponderance decreased in the order of $\mathrm{Na}^{+}>$ $\mathrm{Ca}^{++}>\mathrm{Mg}^{++}>\mathrm{K}^{+}$and the anionic preponderance decreased in the order of $\mathrm{SO}_{4}^{2-}>$ $\mathrm{Cl}^{-}>\mathrm{HCO}_{3}^{-}$in this area. Concentration of soluble $\mathrm{CO}_{3}^{2-}$ was nil. Sodium sulphate predominated over sodium chloride salt. When the saline soils were pre incubated at moisture content of $50 \%$ of water holding capacity to minimize water stress, the electrical conductivity of the samples remained same but the osmotic potential of the soils increased on an average of 8 folds, osmotic stress decreased to $84 \%$ (Figure 2).

Soil $\mathrm{pH}$ varied between 4.43 and 6.64 (Table 1), and it was the lowest in soil S11 where the $E C_{e}$ was the highest. Soil $\mathrm{pH}$ decreased with increase in electrical conductivity of the soils $(r=-0.58)$, but not sufficiently to a great extend to impact biological activity. It is noticeable that soil $\mathrm{pH}$ was moderately acidic in samples of the valley area and gradually decreased (more acidic) towards the sea. The clay content varied from $41 \%$ in $\mathrm{S} 7$ to $50 \%$ in S1 (Table 1 ).

The textural classes of the soils were clay. Clay soils are actually chosen for rice cultivation for its higher water holding capacity. Moisture contents of the collected soil samples varied from $2.41 \%$ to $21.43 \%$, being the lowest in S5 and the highest in S1. Moisture contents were significantly negatively correlated with the increasing gradients of $E C_{\mathrm{e}} \mathrm{s}(r=-0.37, p<0.05)$. Soils which were relatively dry during sample collection consisted more salts in it. The organic carbon content varied from $0.91 \%$ to $1.89 \%$ (Table 1). It was low in nonsaline soils (S1 and S2). The organic carbon content was

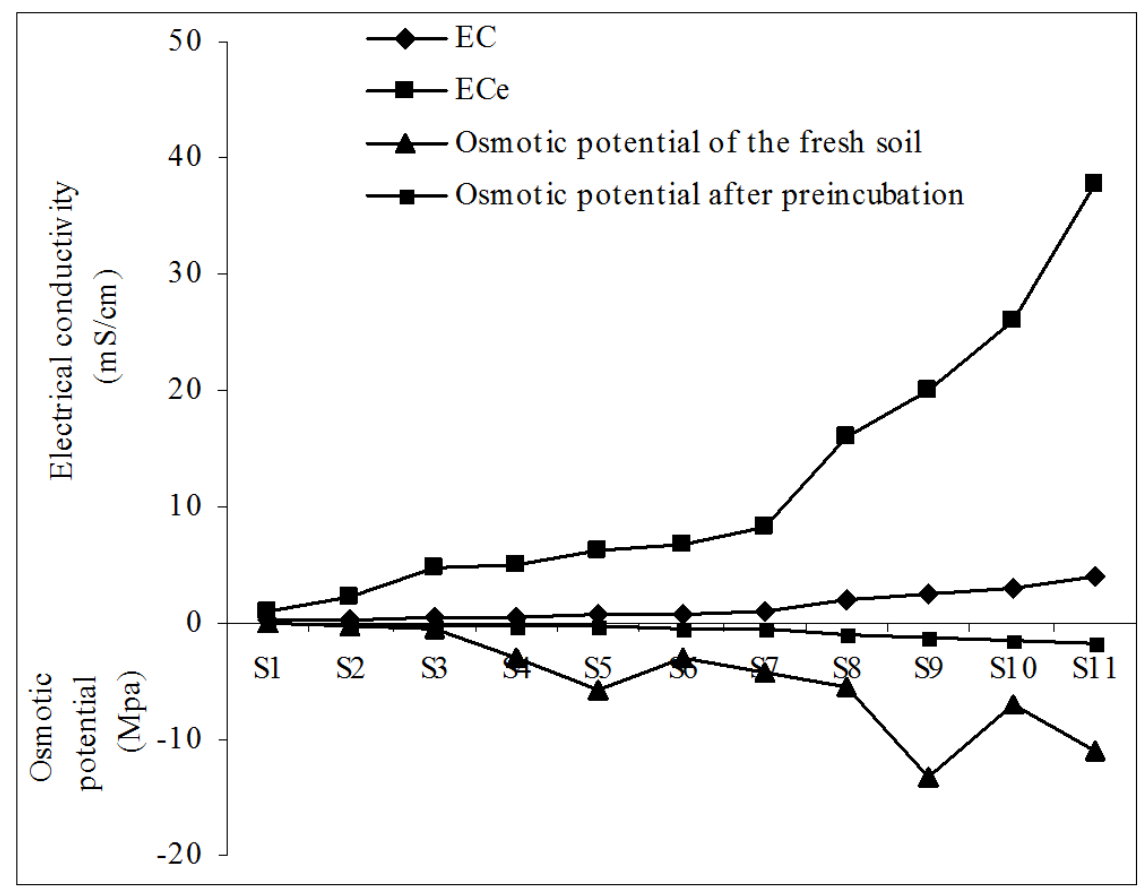

Figure 2. EC (Electrical conductivity at 1:5 soil water ratios), $E C_{e}$ (Electrical conductivity at saturated paste condition), Osmotic potential at natural condition and Osmotic potential after pre incubation at optimum moisture condition of the 11 soil samples. ( $n=3$, standard error bars are smaller than the symbols). 
positively correlated with $E C_{e}(r=0.88, p<0.05)$. The average soil organic carbon concentration was $0.98 \%, 1.27 \%, 1.49 \%$, and $1.72 \%$ in the nonsaline, moderately saline, highly saline and extremely saline soils respectively. The sampling sites were agricultural land where rice was cultivated during the monsoon season. Generally salinity-induced degradation in soils is characterized by low soil organic carbon values [23], but in this study there was an increase in soil organic carbon content with increasing salinity (Table 1). Both [24] and [25] reported accumulation of organic matter in saline soils.

\subsection{Soil Microbiological Properties}

\subsubsection{Soil Microbial Population}

A $\log _{10}$ counted number of culturable bacteria and fungi cells in colony forming unit per gram soil (CFU/g) in the soils are shown in Figure 3(a) and Figure 3(b) respectively. The number of bacteria $\left(\log _{10} 7.46 \mathrm{CFU} / \mathrm{g}\right)$ and fungi $\left(\log _{10} 5.28 \mathrm{CFU} / \mathrm{g}\right)$ of nonsaline soils were significantly $(p<0.001)$ different from the number of bacteria $\left(\log _{10}\right.$ $7.04 \mathrm{CFU} / \mathrm{g})$ and fungi $\left(\log _{10} 4.95 \mathrm{CFU} / \mathrm{g}\right)$ of the extremely saline soils. Higher organic matter content of the saline soils and suitable moisture content after pre incubation could not help soil bacteria and fungi substantially to overcome salinity effect. The fungi-to-bacteria ratio decreased with increasing salinity, revealing bacterial dominance in the decomposer community (Figure 3(c)). Fungi-to-bacteria ratio can decrease in saline soils as fungi are more sensitive to salt stress than bacteria [25] [26]. Saline environments harbor taxonomically diverse bacterial groups, which exhibit modified physiological and structural characteristics under the prevailing saline conditions [27].

\subsubsection{Microbial Biomass Carbon}

Microbial biomass carbon had declined in all the saline soils and showed clear variations among the soils of different salinity (Figure $3(\mathrm{~d})$ ). The biomass carbon was the highest in soil S1 (with lowest $E C_{e}$ ) and the lowest in soil S11 (with highest $E C_{e}$ ) and the values in S5 and S11 were lower by 1.50 and 4.50 folds compared to soil S1. The negative relationship $(r=-0.95, p<0.001)$ between microbial biomass carbon and $E C_{e}$ demonstrates that salinity has adverse effect on the soil microbial community. This finding is similar to the results found in naturally saline soils, where microbial biomass was negatively correlated with increasing salinity [28]. References [23] and [26] observed a decrease in microbial biomass with increasing salinity. The percentage of microbial biomass of the total soil organic matter is a sensitive measure to show direct salt effects [29]. The percentage of microbial biomass of the total soil organic matter also decreased in soils with higher salinity suggesting that a direct negative effect $(r=-0.86, p<0.05)$ on soil microbial biomass exists (Figure 3(e)).

\subsubsection{Metabolic Quotient}

Microbial metabolic quotient $\left(\mathrm{qCO}_{2}\right)$ is used as indicator for the effect of stress on biological activity through estimating the efficiently of microbial biomass to utilize available carbon for biosynthesis [23]. The $\mathrm{qCO}_{2}$ value tends to be higher in adverse conditions such as in heavy metal contamination [30], low soil $\mathrm{pH}$ [31] and fluctuating salinity [32]. 


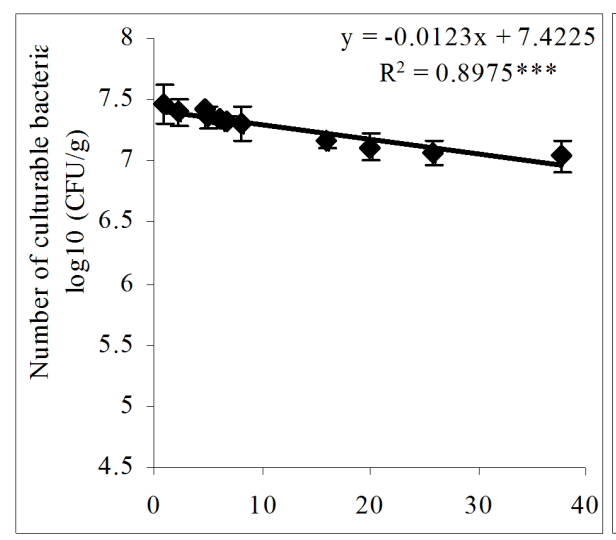

(a)

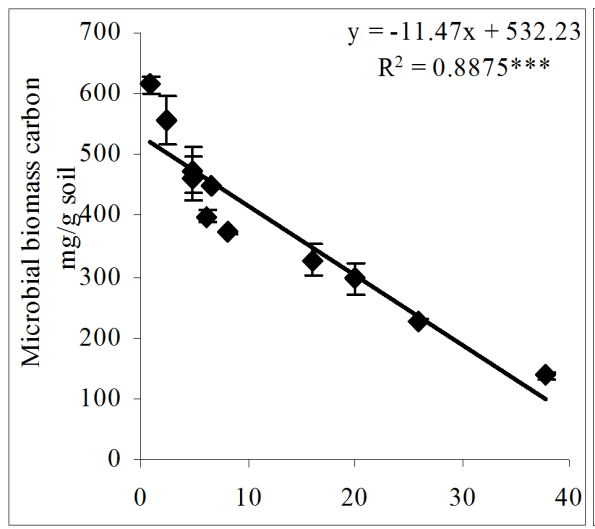

(d)

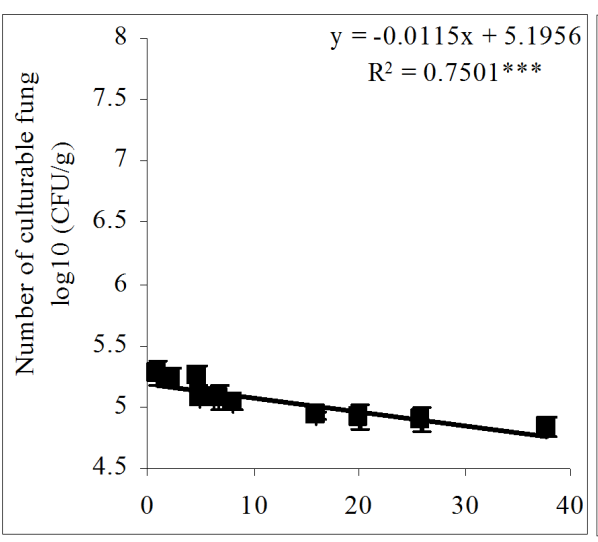

(b)

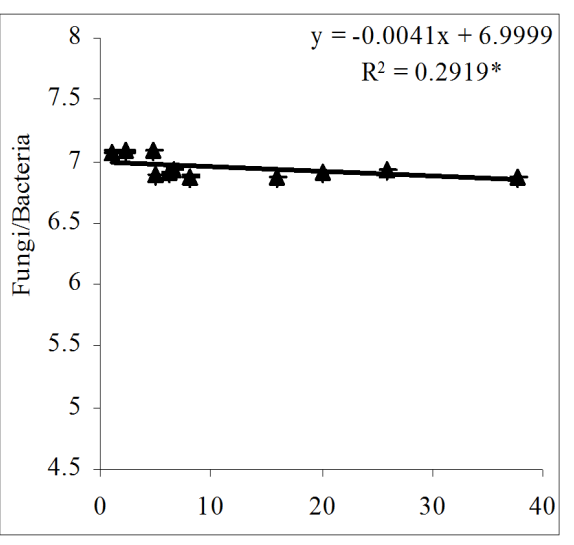

(c)

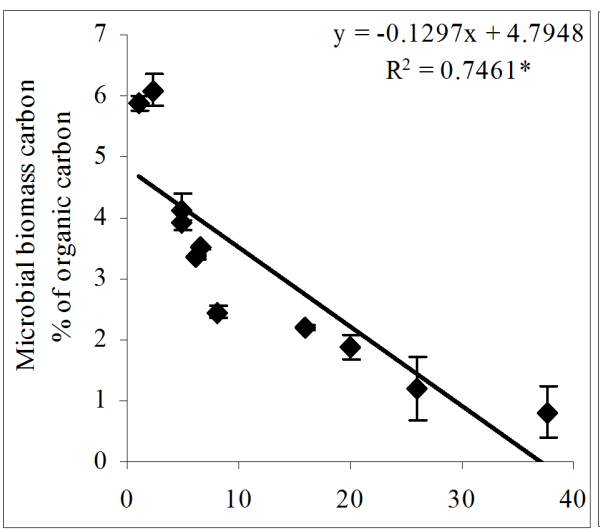

Electrical conductivity (mS/cm)

(e)

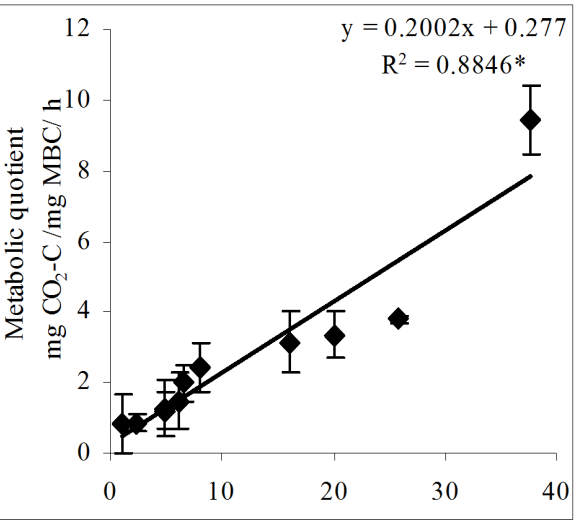

(f)

Figure 3. Relationship of microbial parameters (a) Number of culturable bacterial cells (b) Number of culturable fungal cells (c) Fungi/Bacteria (d) Microbial biomass carbon (d) Microbial biomass carbon in percentage of respective total soil organic matter content (e) Metabolic quotient with electrical conductivity in the coastal soils of Banshkhali, Chittagong $(\mathrm{n}=3)$. Regression equation, line of best fit and level of statistical significance shown. $\left(^{*}\right) p<0.05,\left({ }^{* *}\right) p<0.01,\left({ }^{* *}\right) p<0.001$.

The metabolic quotient increased as the gradient of $E C_{e}$ increased (Figure 3(f)). There was a steep initial increased in metabolic quotient up to $E C_{e} 6.16 \mathrm{mS} / \mathrm{cm}$, after which the increase was less marked. The metabolic quotient varied from $1.21 \mathrm{mg} \mathrm{CO}_{2}-\mathrm{C} / \mathrm{mg}$ biomass $\mathrm{C} / \mathrm{h}$ to $9.43 \mathrm{mg} \mathrm{CO}$ - $\mathrm{C} / \mathrm{mg}$ biomass- $\mathrm{C} / \mathrm{h}$ in saline soils. The positive relationship between $\mathrm{qCO}_{2}$ and $E C_{e}$ indicates the increasing salinity in soil causing stress to the soil microbial community.

\subsubsection{Microbial Activity}

Soil respiration rate is used to monitor microbial activity. The respiration rate was lower in nonsaline soils compared to saline soils. On day 1 , average microbial respiration was $0.50 \mathrm{mg} \mathrm{CO} / \mathrm{h}$ in soils at $E C_{e}$ value of $>4.00 \mathrm{mS} / \mathrm{cm}$. The $\mathrm{CO}_{2}$ production rate increased at higher electrical conductivity levels from $E C_{e} 4.81$ to 6.63 with average value of $0.81 \mathrm{mg} \mathrm{CO} / \mathrm{h}$. After this level respiration rate increased to 1.83 to $2.56 \mathrm{mg} \mathrm{CO} / \mathrm{h}$ with average value of $2.36 \mathrm{mg} \mathrm{CO} / \mathrm{h}$ in soils with $E C_{e}$ between 8.13 to $25.89 \mathrm{mS} / \mathrm{cm}$. Soils with $E C_{e} 37.73 \mathrm{mS} / \mathrm{cm}$, the respiration rate increased to the level $2.81 \mathrm{mg} \mathrm{CO} / \mathrm{h}$. 
The respiration rates were found to be 5 folds higher than the nonsaline soils where $E C_{e}$ was more than 16. The rates of $\mathrm{CO}_{2}$ evolution in saline soils were pronounced during the first ten days of incubation period. However, differences on rate of $\mathrm{CO}_{2}$ evolution between soils with different salinity levels become lower as incubation advanced (Figure 4). The regression analysis $\left(y=0.39 x+0.79, R^{2}=0.97\right)$ indicated that cumulative soil respiration increased with increasing gradients of soil $E C_{e} s$ (after 30 days). The lack of a significant negative correlation between microbial activity and $E C_{e}$ is surprising as microflora generally control the mineralization of organic carbon in soil. With increasing $E C_{e}$ increase in basal respiration was reported in [23] [24]. Reference [33] found a steady evolution of $\mathrm{CO}_{2}$ throughout 3 months of high salinity treatment. Low concentrations of salt in solution had a stimulation effect on carbon mineralization but after certain level at higher concentrations become toxic to the organisms [34]. Reference [23] observed the linear increase in soil respiration with increasing salinity, where the soil samples were at $60 \%$ of water holding capacity and organic matter content of their soils were on average $2 \%$.

Low soil moisture content is more detrimental to microorganisms than low osmotic potential from soil salinity at optimal soil moisture condition [4]. The set up of the incubation experiment in this experiment at optimum moisture condition might offset some of the stresses placed on the adapted microbial population from high salt concentrations during the dry phase [18] [35]. Reference [36] related the decomposition of organic matter under salt stress to the soil water content. Significant $\mathrm{CO}_{2}$ evolution was observed at very high salinity with $E C_{e}$ of $37.73 \mathrm{mS} / \mathrm{cm}$. The adaptation mechanism in saline soils costs higher carbon mineralization with a higher physiological activity which results in increased soil respiration and, in consequence, reduced substrate use efficiency (high $\mathrm{qCO}_{2}$ ). Moreover, the salinity in the study area is due to salts other than

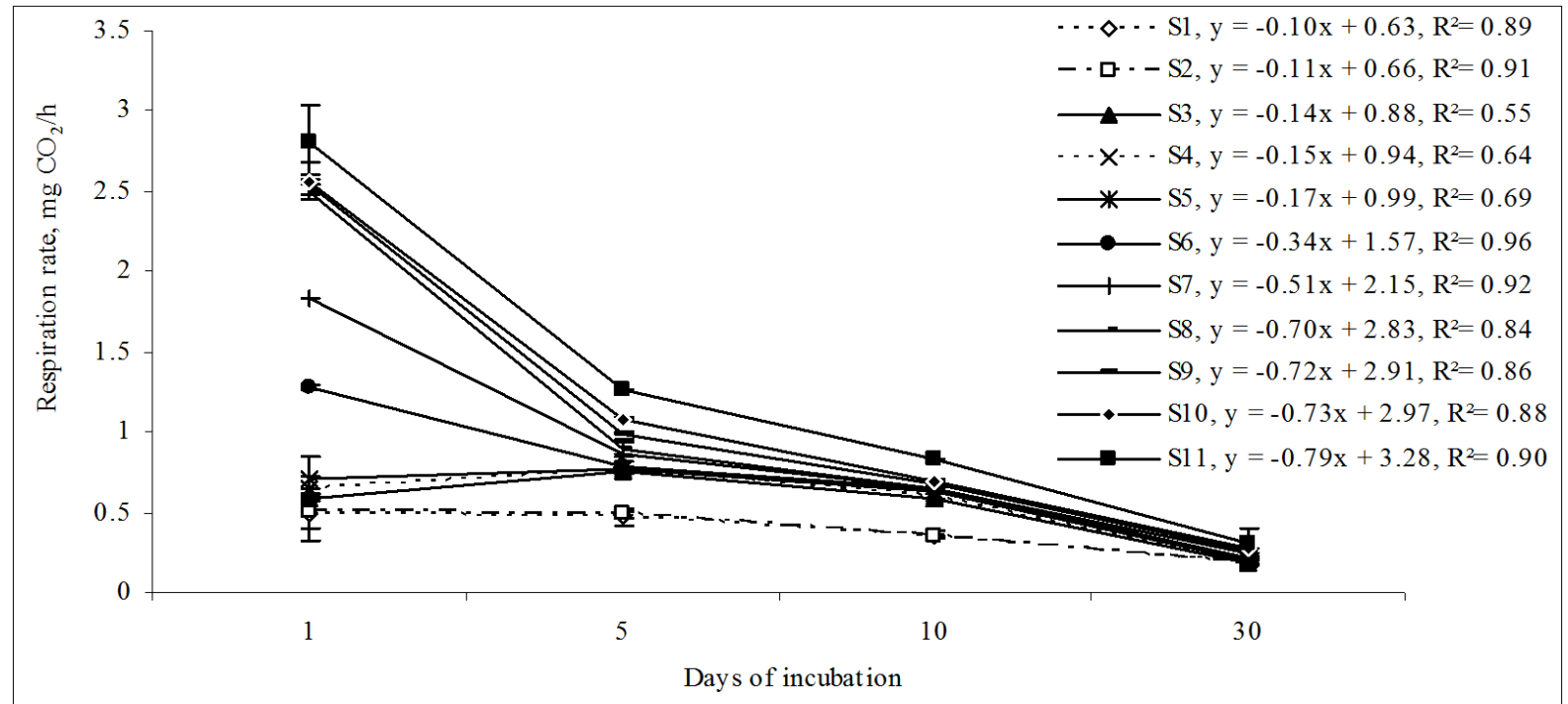

Figure 4. Relationship of soil respiration rate during the incubation experiment (30 days) with electrical conductivity in the coastal soils of Banshkhali, Chittagong. Error bars indicate standard deviations $(n=3)$. Regression equation and $R^{2}$ were shown. 
$\mathrm{NaCl}$ which are less toxic, which can be another reason of reduced salt effect. The microbial activity was found being less affected in the saline soils where salinity imposed by $\mathrm{Na}_{2} \mathrm{SO}_{4}$ than that of $\mathrm{NaCl}$ [36]. Sulfate salts were less toxic to nitrification than chloride salts [37].

\subsection{Impacts of Rice Straw Incorporation on the Responses of Soil Microbial Biomass and Activity}

The amount of microbial biomass carbon and activity increased after substrate application in both nonsaline and saline soils from day 0 to day 30 in all treatments (Table 2). Increase in microbial biomass carbon and activity was the greatest in the soils which had the lowest microbial biomass on day 0 , i.e. soil S11, which was also the soil with maximum $E C_{e}$. The trend of increase, increased with the increasing amount of substrate application being the highest at the $2.00 \%$ residue.

After 30 days, the increase in microbial biomass carbon was 4, 7, 14, 15 and 14 folds higher for $0.50 \%, 1.00 \%, 1.50 \%$ and $2.00 \%$ residue application respectively than the microbial biomass carbon content at day 0 in the soils. At a given residue treatment, there was no significant difference in cumulative $\mathrm{CO}_{2}$-carbon between saline soils, not even with the highest salinity. Respirations rate increased with increasing residue applications but with time the difference decreased. This can be due to greater substrate availability per unit microbial biomass in the saline soils. The incorporation of organic amendments to soil stimulates microbial activity. Amendment of organic matter improves soil quality under saline conditions and counteracts the negative effects of salt, because soil microorganisms profit from a higher substrate availability and can more easily cope with high salinity [25]. Other studies in saline soils have shown that microbial biomass is positively correlated with the amounts of labile carbon [29] [38]. This study suggests that the saline soil of this study has a subset of microbes that can become active and decompose added substrate even at the extreme saline condition. According to [39], these stressed microorganisms from extremely saline soils can respond quickly with an increase in activity if the stress of soil salinity is reduced after rainfall or irrigation.

\subsection{Selection of Substrate Application Rate}

There was an increase in microbial respiration with increasing residue rate along with $E C_{e}$. Data pooled over the 30 days showed that respiration rate within each soil increased with increasing the substrate incorporation rate being highest at the $2.00 \%$ residue.

When cumulative $\mathrm{CO}_{2}$ after 30 days was plotted against $E C_{e}$ at each residue rate, the maximum slope of the regression line was found at the $1.00 \%$ residue rate (Table 3 ). Thus, the clearest differences between different salinity levels were obtained at a rate of $1.00 \%$ residue. There were no significant variations between the cumulative respirations and microbial biomass content with $0.00 \%$ and $0.50 \%$ residue applications in all the soils. Again the biological parameters in residue treatment $1.00 \%, 1.50 \%$ and $2.00 \%$ were 
Table 2. Relationship of cumulative respiration with electrical conductivity after 30 days in the coastal soils (amended with rice residues at five different rates) of Banshkhali, Chittagong.

\begin{tabular}{|c|c|c|c|c|c|c|}
\hline \multirow{2}{*}{$\begin{array}{c}\text { Soil } \\
\text { Sample }\end{array}$} & \multirow{2}{*}{$\begin{array}{c}E C_{e} \\
(\mathrm{mS} / \mathrm{cm})\end{array}$} & \multicolumn{5}{|c|}{ Residue rates (\%) } \\
\hline & & 0.00 & 0.05 & 1.00 & 1.50 & 2.00 \\
\hline S1 & 0.98 & $5.79 \pm 0.52 \mathrm{a}$ & $66.63 \pm 0.50 \mathrm{a}$ & $360.81 \pm 0.56 \mathrm{a}$ & $468.39 \pm 0.24 \mathrm{a}$ & $576.11 \pm 1.20 \mathrm{a}$ \\
\hline S2 & 2.33 & $6.51 \pm 0.28 \mathrm{a}$ & $80.43 \pm 0.11 a$ & $472.06 \pm 0.37 b$ & $540.17 \pm 0.81 \mathrm{~b}$ & $728.64 \pm 1.62 \mathrm{a}$ \\
\hline S3 & 4.81 & $14.30 \pm 0.14 b$ & $154.33 \pm 0.53 \mathrm{bcd}$ & $966.38 \pm 6.66 \mathrm{e}$ & $976.73 \pm 0.48 \mathrm{~cd}$ & $1039.88 \pm 0.29 b c$ \\
\hline S4 & 4.9 & $15.66 \pm 0.12 b$ & $168.86 \pm 0.20 \mathrm{~d}$ & $919.84 \pm 0.20 \mathrm{de}$ & $936.72 \pm 0.06 c$ & $904.63 \pm 0.33 b c$ \\
\hline S5 & 6.16 & $15.18 \pm 1.09 \mathrm{~b}$ & $160.12 \pm 0.90 \mathrm{bcd}$ & $809.45 \pm 0.54 c$ & $886.18 \pm 0.30 \mathrm{~b}$ & $985.46 \pm 0.09 \mathrm{bcd}$ \\
\hline S6 & 6.63 & $14.37 \pm 0.24 b$ & $158.55 \pm 1.26 \mathrm{bcd}$ & $812.44 \pm 0.42 c$ & $902.07 \pm 0.96 b c$ & $996.86 \pm 0.15 \mathrm{~cd}$ \\
\hline S7 & 8.13 & $12.91 \pm 0.44 \mathrm{~b}$ & $139.98 \pm 0.64 \mathrm{ab}$ & $761.06 \pm 0.08 c$ & $922.99 \pm 0.45 b c$ & $985.74 \pm 0.79 b c d$ \\
\hline S8 & 16.03 & $14.37 \pm 0.08 b$ & $162.12 \pm 0.87 \mathrm{~cd}$ & $910.77 \pm 1.80 \mathrm{~cd}$ & $893.50 \pm 0.64 b$ & $935.43 \pm 0.08 c$ \\
\hline S9 & 20.09 & $14.10 \pm 0.51 b$ & $157.10 \pm 0.02 b c$ & $829.97 \pm 0.38 \mathrm{~d}$ & $892.71 \pm 0.08 b$ & $990.60 \pm 0.01 d$ \\
\hline S10 & 25.89 & $16.89 \pm 2.15 c$ & $156.40 \pm 0.32 b c$ & $840.52 \pm 1.05 \mathrm{~cd}$ & $858.22 \pm 0.20 \mathrm{~b}$ & $865.28 \pm 0.12 c$ \\
\hline S11 & 37.73 & $15.24 \pm 4.61 b$ & $175.98 \pm 2.09 \mathrm{e}$ & $817.79 \pm 0.42 c$ & $854.28 \pm 0.03 b$ & $898.41 \pm 0.14 c$ \\
\hline
\end{tabular}

Each mean is the average of the values obtained for three samples of each soil. Values in the same column followed by the same letter(s) are not significantly different at $\mathrm{p}<0.05$ according to ANOVA.

Table 3. Relationship between electrical conductivity and cumulative $\mathrm{CO}_{2}$-carbon evolved at $0 \%$ $2 \%(\mathrm{w} / \mathrm{w})$ rice residue addition and carbon mineralization rate constants, $k$ as affected by added residues.

\begin{tabular}{ccccccc}
\hline & & & \multicolumn{5}{c}{ K (per day) } \\
\cline { 5 - 7 } Residue rate (\%) & Regression equation & $R^{2}$ & Nonsaline & $\begin{array}{c}\text { Moderately } \\
\text { saline }\end{array}$ & $\begin{array}{c}\text { Highly } \\
\text { saline }\end{array}$ & $\begin{array}{c}\text { Extremely } \\
\text { saline }\end{array}$ \\
\hline 0.00 & $y=3.17 x+3.69$ & 0.94 & 0.00 & 0.03 & 0.01 & 0.05 \\
0.05 & $y=32.57 x+44.64$ & 0.90 & 0.07 & 0.03 & 0.03 & 0.05 \\
1.00 & $y=219.59 x+128.64$ & 0.91 & 0.10 & 0.10 & 0.06 & 0.08 \\
1.50 & $y=126.09 x+432.55$ & 0.83 & 0.08 & 0.06 & 0.07 & 0.06 \\
2.00 & $y=90.008 x+609.58$ & 0.80 & 0.09 & 0.07 & 0.04 & 0.06 \\
\hline
\end{tabular}

significantly different $(p<0.05)$ from treatment $0.00 \%$ and $0.50 \%$ in all the soils, but not significantly different to each other. The carbon mineralization rate constants, $\mathrm{k}$ also increased with increasing residue addition rate up to $1.00 \%$ and then remained variable with $1.50 \%$ and $2.00 \%$ residue application (Table 3 ). It can be possible that small increase in microbial biomass at low residue addition rates may be unable to decompose the residues at high rates [40]. Another way, carbon can be immobilized to the soils where the treatments $1.50 \%$ and $2.00 \%$ were applied. During rice cultivation long flooding periods are maintained, which can facilitate the anaerobic decomposition of organic substrate. Therefore excessive use of organic substrates in rice field should be avoided which can increase the risk of toxic effects from reduced intermediates. Therefore, the rate of rice residue application can be suggested to $1.00 \%$ to the soils for suc- 
cessful amelioration of saline soils of the study area.

\section{Conclusion}

According to the findings of this study, salt affected soils of coastal area of Chittagong can be managed profitably. This area is an important land resource for agriculture in Bangladesh. Management of saline soils with proper residues and water can make the soil productive. Further studies are needed in the field to get the goal to achieve maximum production from these lands. These studies are important in perspective of Bangladesh as land for agriculture is decreasing due to high population pressure.

\section{Acknowledgements}

I am grateful to Dr. Khan Towhid Osman and Dr. S. M. Sirajul Haque for useful discussion and Mir. Shahabuddin for soil sample collection. The technical assistance of Md. Mamunur Rasid and Md. Tazul Islam is highly appreciated. This work was supported by the University Grant Commission, Bangladesh.

\section{References}

[1] Hoque, M.A., Saika, U., Sarder, B.C. and Biswas, K.K. (2013) Environmental and SocioEconomic Impacts of Salinity Intrusion in the Coastal Area: A Case Study on Munshigong Union, Shymnagor, Satkhira. Jahangirnagar University Environmental Bulletin, 2, 41-49. http://dx.doi.org/10.3329/jueb.v2i0.16329

[2] Haque, S.A. (2006) Salinity Problems and Crop Production in Coastal Regions of Bangladesh. Pakistan Journal of Botany, 38, 1359-1365.

[3] Yuan, B.C., Xu, X.G., Li, Z.Z., Gao, T.P., Gao, M., Fan, X.W. and Deng, H.M. (2007) Microbial Biomass and Activity in Alkalized Magnesic Soils under Arid Conditions. Soil Biology and Biochemistry, 39, 3004-3013. http://dx.doi.org/10.1016/j.soilbio.2007.05.034

[4] Chowdhury, N., Marschner, P. and Burns, R. (2011) Response of Microbial Activity and Community Structure to Decreasing Soil Osmotic and Matric Potential. Plant and Soil, 344, 241-254. http://dx.doi.org/10.1007/s11104-011-0743-9

[5] Oren, A. (1999) Bioenergetic Aspects of Halophilism. Microbiology and Molecular Biology Reviews, 63, 334-348.

[6] Hossain, N., Muhibbullah, M., Ali, K.M.B. and Molla, M.H. (2015) Relationship between Soil Salinity and Physico-Chemical Properties of Paddy Field Soils of Jhilwanja Union, Cox's Bazar, Bangladesh. The Journal of Agricultural Science, 7, 166-180. http://dx.doi.org/10.5539/jas.v7n10p166

[7] Huq, S.M.I. and Shoaib, J.U.M. (2013) The Soils of Bangladesh. Springer Science and Business Media, Dordrecht. http://dx.doi.org/10.1007/978-94-007-1128-0

[8] [SRDI] Soil Resource and Development Institute Staffs (2010) Saline Soils of Bangladesh. Soil Resources Development Institute, Dhaka, 1-15.

[9] Richard, L.A. (1954) Diagnosis and Improvement of Saline and Alkali Soils. US Department of Agriculture. Agricultural Handbook No. 60, Washington DC, 7-53. http://dx.doi.org/10.1097/00010694-195408000-00012

[10] Rengasamy, P. (2006) Soil Salinity and Sodicity. In: Stevens, D., Ed., Growing Crops with Reclaimed Waste Water, CSIRO Publishing, Melbourne, 125-138. 
[11] Campbell, R.B., Bower, C.A. and Richards, L.A. (1948) Change of Electrical Conductivity with Temperature and the Relation of Osmotic Pressure to Electrical Conductivity and Ion Concentration for Soil Extract. Soil Science Society of America, Proceedings, 66-69.

[12] Jackson, M.L. (1973) Soil Chemical Analysis. Prentice Hall of India, New Delhi, 41-330.

[13] Day, P.R. (1965) Particle Fractionation and Particle Size Analysis. In: Black, C.A., Evans, D.D., Ensminger, L.E., White, J.L. and Clark, F.E., Eds., Methods of Soil Analysis, American Society of Agronomy, Soil Science Society of America, Madison, 545-566.

[14] Nelson, D.W. and Sommers, L.E. (1982) Total Carbon, Organic Carbon and Organic Matter. In: Page, A.L., Miller, R.H. and Keeney, D.R., Eds., Methods of Soil Analysis: Chemical and Microbiological Properties, American Society of Agronomy, Soil Science Society of America, Madison, 539-579.

[15] Johnson, L.F. and Curl, E.A. (1972) Methods for Research on the Ecology of Soil-Borne Plant Pathogens. Burgess Publishing Company, Minneapolis.

[16] Jenkinson, D.S. and Powlson, D.S. (1976) The Effects of Biocidal Treatments on Metabolism in Soil-V: A Method for Measuring Soil Biomass. Soil Biology and Biochemistry, 8, 209-213. http://dx.doi.org/10.1016/0038-0717(76)90005-5

[17] Wu, J., Joergensen, R.G., Pommering, B., Chaussod, R. and Brookes, P.C. (1990) Measurement of Soil Microbial Biomass C-an Automated Procedure. Soil Biology and Biochemistry, 22, 1167-1169. http://dx.doi.org/10.1016/0038-0717(90)90046-3

[18] Wong, V.N.L., Dalal, R.C. and Greene, R.S.B. (2008) Salinity and Sodicity Effects on Respiration and Microbial Biomass of Soil. Biology and Fertility of Soils, 44, 943-953.

http://dx.doi.org/10.1007/s00374-008-0279-1

[19] Anderson, T.H. and Domsch, K.H. (1990) Application of Eco-Physiological Quotients ( $q \mathrm{CO}_{2}$ and $q \mathrm{D}$ ) on Microbial Biomasses from Soils of Different Cropping Histories. Soil Biology and Biochemistry, 22, 251-255. http://dx.doi.org/10.1016/0038-0717(90)90094-G

[20] Alef, K. (1995) Soil Respiration. In: Alef, K. and Nannipieri, P., Eds., Methods in Soil Microbiology and Biochemistry, Academic Press Inc., San Diego, 214-215.

[21] Rodella, A.A. and Saboya, L.V. (1999) Calibration of Conductimetric Determination of Carbon Dioxide. Soil Biology and Biochemistry, 31, 2059-2060.

http://dx.doi.org/10.1016/S0038-0717(99)00046-2

[22] Moslehuddin, A.Z.M., Abedin, M.A., Hossain, M.A.R. and Habiba, U. (2015) Soil Health and Food Security: Perspective from Southwestern Coastal Region of Bangladesh. In: Habiba, U., Hassan, A.W.R., Abedin, M.A. and Shaw, R., Eds., Food Security and Risk Reduction in Bangladesh, Springer, Berlin, 187-212. http://dx.doi.org/10.1007/978-4-431-55411-0 11

[23] Rietz, D.N. and Haynes, R.J. (2003) Effects of Irrigation-Induced Salinity and Sodicity on Soil Microbial Activity. Soil Biology and Biochemistry, 35, 845-854. http://dx.doi.org/10.1016/S0038-0717(03)00125-1

[24] Rasul, G., Appuhn, A., Müller, T. and Joergensen, R.G. (2006) Salinity-Induced Changes in the Microbial Use of Sugarcane Filter Cake Added to Soil. Applied Soil Ecology, 31, 1-10. http://dx.doi.org/10.1016/j.apsoil.2005.04.007

[25] Wichern, J., Wichern, F. and Joergensen, R.G. (2006) Impact of Salinity on Soil Microbial Communities and the Decomposition of Maize in Acidic Soils. Geoderma, 137, 100-108. http://dx.doi.org/10.1016/j.geoderma.2006.08.001

[26] Sardinha, M., Müller, T., Schmeisky, H. and Joergensen, R.G. (2003) Microbial Performance in Soils along a Salinity Gradient under Acidic Conditions. Applied Soil Ecology, 23, 237-244. http://dx.doi.org/10.1016/s0929-1393(03)00027-1 
[27] Zahran, H.H. (1997) Diversity, Adaptation and Activity of the Bacterial Flora in Saline Environments. Biology and Fertility of Soils, 25, 211-223.

http://dx.doi.org/10.1007/s003740050306

[28] Yan, N. and Marschner, P. (2012) Microbial Activity and Biomass Recover Rapidly after Leaching of Saline Soils. Biology and Fertility of Soils, 49, 367-371.

http://dx.doi.org/10.1007/s00374-012-0733-y

[29] Rath, K. and Rousk. J. (2015) Salt Effects on the Soil Microbial Decomposer Community and Their Role in Organic Carbon Cycling: A Review. Soil Biology and Biochemistry, 81, 108-123. http://dx.doi.org/10.1016/j.soilbio.2014.11.001

[30] Jiang, J., Wu, L., Li, N., Luo, Y., Liu, L., Zhao, Q., Zhang, L. and Christie, P. (2010) Effects of Multiple Heavy Metal Contamination and Repeated Phytoextraction by Sedum plumbizincicola on Soil Microbial Properties. European Journal of Soil Biology, 46, 18-26. http://dx.doi.org/10.1016/j.ejsobi.2009.10.001

[31] Wolters, V. and Joergensen, R.G. (1991) Microbial Carbon Turnover in Beech Forest Soils at Different Stages of Acidification. Soil Biology and Biochemistry, 23, 897-902. http://dx.doi.org/10.1016/0038-0717(91)90103-Q

[32] Sarig, S. and Steinberger, Y. (1994) Microbial Biomass Response to Seasonal Fluctuation in Soil Salinity under the Canopy of Desert Halophytes. Soil Biology and Biochemistry, 26, 1405-1408. http://dx.doi.org/10.1016/0038-0717(94)90224-0

[33] Pathak, H. and Rao, D.L.N. (1998) Carbon and Nitrogen Mineralization from Added Organic Matter in Saline and Alkali Soils. Soil Biology and Biochemistry, 30, 695-702. http://dx.doi.org/10.1016/S0038-0717(97)00208-3

[34] Chandra, S., Joshi, H.C., Pathak, H., Jain, M.C. and Kalra, N. (2002) Effect of Potassium Salts and Distillery Effluent on Carbon Mineralization in Soil. Bioresource Technology, 83, 255-257. http://dx.doi.org/10.1016/S0960-8524(01)00230-9

[35] Fierer, N. and Schimel, J.P. (2003) A Proposed Mechanism for the Pulse in Carbon Dioxide Production Commonly Observed Following the Rapid Rewetting of a Dry Soil. Soil Science Society of America Journal, 67, 798-805. http://dx.doi.org/10.2136/sssaj2003.0798

[36] Li, X., Li, F., Singh, B., Cui, Z. and Rengel, Z. (2006) Decomposition of Maize Straw in Saline Soil. Biology and Fertility of Soils, 42, 366-370. http://dx.doi.org/10.1007/s00374-005-0042-9

[37] Garcia, C. and Hernandez, T. (1996) Influence of Salinity on the Biological and Biochemical Activity of a Calciorthird Soil. Plant and Soil, 178, 255-263. http://dx.doi.org/10.1007/BF00011591

[38] Elgharably, A. and Marschner, P. (2011) Microbial Activity and Biomass and N and P Availability in a Saline Sandy Loam Amended with Inorganic N and Lupin Residues. European Journal of Soil Biology, 47, 310-315. http://dx.doi.org/10.1016/j.ejsobi.2011.07.005

[39] Naeem Asghar, H., Setia, R. and Marschner, P. (2012) Community Composition and Activity of Microbes from Saline Soils and Non-Saline Soils Respond Similarly to Changes in Salinity. Soil Biology and Biochemistry, 47, 175-178. http://dx.doi.org/10.1016/j.soilbio.2012.01.002

[40] Setia, R., Marschner, P. and Chittleborough, D.B.J. (2010) Is $\mathrm{CO}_{2}$ Evolution in Saline Soils Affected by an Osmotic Effect and Calcium Carbonate? Biology and Fertility of Soils, 46, 781-792. http://dx.doi.org/10.1007/s00374-010-0479-3 
Submit or recommend next manuscript to SCIRP and we will provide best service for you:

Accepting pre-submission inquiries through Email, Facebook, LinkedIn, Twitter, etc. A wide selection of journals (inclusive of 9 subjects, more than 200 journals)

Providing 24-hour high-quality service

User-friendly online submission system

Fair and swift peer-review system

Efficient typesetting and proofreading procedure

Display of the result of downloads and visits, as well as the number of cited articles

Maximum dissemination of your research work

Submit your manuscript at: http://papersubmission.scirp.org/

Or contact ojss@scirp.org 